\title{
Noise Survey of the University of Port Harcourt Teaching Hospital
}

\author{
Nte F.U, Gbarato O.L.
}

\begin{abstract}
Noise survey of the University of Port Harcourt Teaching Hospital " $A$ ", " $B$ " = class room environment and "C" $\mathrm{C}$ Hostel environment of the University of Port Harcourt was carried. The study permit by the ethics committees was obtained and covers noise evaluation of the teaching hospital environment. The noise ranged $52 \mathrm{dBA}$ around the wards, 72 $\mathrm{dBA}$ around the Motor Park and 112dBA at generator yard of the utility unit. Noise level around the class rooms " $B$ " ranged $57 \mathrm{dBA}$ while lectures are on and $75 \mathrm{dBA}$ when lectures are over, depending on the hall size. The University hostel areas "C" had noise level of 55 dBA during examination week and $78 \mathrm{dBA}$ during the student union week due to games, politics and cultural activities with high electronic sound blast. The statistical analyses of the minimum and maximum range is reflected in tables1, 2, 3 which shows a very high variability between the minimum $A$ and maximum $A$ while maximum $B$ and maximum $C$ shows a great correlation. A participatory interphase shows that electronic, radio and television noise, including telephone calls and crowed of visitors can affect the next inmate psychologically and health wise beyond the sound intensity because of compact bed spaced despite visiting hours, the hostels and open wards needs health educators while side room- experience is different and effectively coordinated in favour of the private hospitals.
\end{abstract}

Index Terms - Acoustic Walls, Noise Attenuation, Noise Survey

\section{INTRODUCTION}

Noise health is tending to the 3rd highest environmental impact area in the universities and health sectors of Nigeria in Africa by this study. The first in the series being waste management and hygiene, the second being mosquito and malaria, closely followed by sound impact and hash climate temperature. The noise evaluation has three dimensions; The physical traumatic impact, associated with blast, the physical impact associated with loss of concentration due to threshold shift in hearing, and the psychological impact association with stress, annoyance and depression. Were as the first is associated with industries, the second with scholarly institutions, the third is highly linked with the health environment, with a greater vulnerability from the shouting snowing telephone calls and general conduct of the next in mate in hospital environment.

The study reveals that the hospital environment recorded an average of 52dBA around the wards due to staff, patient and patient relations traffic pressure and talking. The park recorded $72 \mathrm{dBA}$ due to motor traffic and the generator house at utility boards recorded $92 \mathrm{dBA}$ due to over working of the generators. The university recorded 52-75 dBA at lecture halls, 55-78dBA at the hostels depending on time and festivities. The noise levels all exceeded the world health organization recommended limits with serious health hazards implication reference fig 1 . Few studies in the area include; [1]-[16].

\section{METHOD}

The study was facilitated by an approval letter from the Teaching Hospital Ethics community for a noise survey of the hospital environment. A CEL 231 and CEL 254 digital noise level meter with A,B,C, D weighting corresponding to low, medium, high and impulsive noise respectively was used along with a global positioning system to track the location. The results and analysis is as reflected in tables 2 , 3,4 , while the scatter trend is as shown on fig $1,2,3$. It was all presided by Table 1 on world health organization standard to drive the impact index.

\section{RESULTS AND DISCUSSION}

The noise survey result of the teaching hospital and the University of Port Harcourt are reflected below under tables 2 to 4 , while the scattering is as shown in figures 1-3. The characterization is reported by [17] which range as follows; 0.00 to 0.20 (slight), 0.21 to 0.21 to 0.40 (Fair), 0.41 to 0.60 to 0.60 (Moderate), 0.61 to 0.80 (Substantial), 0.81 to 1.00 (Almost perfect), also called Level of reliability .

Nte, Felix Ugbana, Environmental Physics; Department of Physics, University of Port Harcourt, Rivers State, Nigeria

Gbarato, Oliver .L, Department of Physics, Ignatius Ajuru University of Education, Rivers State, Nigeria 
Table 1: Noise health index by WHO (WHO, 2014).

\begin{tabular}{|l|l|l|l|}
\hline ENVIRONMENT & CRITICAL HEALTH EFFECT & $\begin{array}{l}\text { SOUND LEVEL } \\
\text { dB(A) }\end{array}$ & TIME (HOURS) \\
\hline Outdoor living areas & Annoyance & $50-55$ & 16 \\
\hline Indoor dwellings & Speech intelligibility & 35 & 16 \\
\hline Bed rooms & Sleep disturbance & 30 & 8 \\
\hline School classrooms & Disturbance of communication & 35 & 24 \\
\hline $\begin{array}{l}\text { Industrial, commercial and traffic } \\
\text { areas }\end{array}$ & Hearing impairment & 70 & 1 \\
\hline Music through ear phones & Hearing impairment & 85 & 4 \\
\hline Ceremonies and entertainment & Hearing impairment & 100 & Duss \\
\hline
\end{tabular}

Source: World Health Organization (WHO), 2005.

Table 2: Correlation (Level of reliability) of the three communities

\begin{tabular}{|c|c|c|c|}
\hline $\begin{array}{l}\text { Paired Samples } \\
\text { statistics }\end{array}$ & Mean \pm Std. Error mean & Correlation & Remark \\
\hline $\begin{array}{l}\text { Min A } \\
\text { Min B }\end{array}$ & $\begin{array}{l}52.08000 \pm 1.32357 \\
52.7700 \pm 0.84334\end{array}$ & $0.135(0.570)$ & Slight \\
\hline $\begin{array}{l}\text { Min A } \\
\text { Min C }\end{array}$ & $\begin{array}{l}51.6143 \pm 1.34145 \\
57.1667 \pm 0.80659\end{array}$ & $0.173(0.453)$ & Slight \\
\hline $\begin{array}{l}\text { Min B } \\
\text { Min C }\end{array}$ & $\begin{array}{l}52.7700 \pm 0.84334 \\
57.1900 \pm 0.84763\end{array}$ & $0.616\left(0.004^{* * *}\right)$ & Substantial \\
\hline $\begin{array}{l}\text { Max A } \\
\text { Max B }\end{array}$ & $\begin{array}{l}67.6950 \pm 2.13758 \\
66.4000 \pm 1.53088\end{array}$ & $-0.367(0.111)$ & Neg. Fair \\
\hline $\begin{array}{l}\text { Max A } \\
\text { Max C }\end{array}$ & $\begin{array}{l}66.6238 \pm 2.29816 \\
70.2714 \pm 0.67831\end{array}$ & $-0.022(0.924)$ & Neg. Slight \\
\hline $\begin{array}{l}\text { Max B } \\
\text { Max }\end{array}$ & $\begin{array}{l}66.4000 \pm 1.53088 \\
70.2550 \pm 0.71276\end{array}$ & $0.097(0.683$ & Slight \\
\hline
\end{tabular}

Footnote: sig at $* * * 1 \%, * * 5 \%$ and $* 10 \%$

The result in Table 1.0 show that only one of intra relationship between the three community blocks ABC are significant, that is the communities $B$ and $C$ for min, while the other five are not significant. The five intra relationships that are not significant are communities Min A against Min. B, Min A against Min C, Max A against Max B, Max A and Max C, Max B against Max C.

Table 3: $t$ - statistics of Maximum and Minimum for three communities (ABC)

\begin{tabular}{|c|c|c|c|c|c|c|c|}
\hline variables & $\begin{array}{l}\text { Mean } \\
\text { difference }\end{array}$ & $\begin{array}{l}\text { Std. } \\
\text { Deviation }\end{array}$ & $\begin{array}{l}\text { Std. Error } \\
\text { Mean }\end{array}$ & \multicolumn{2}{|c|}{$\begin{array}{l}\text { 95\% Confidence Interval of the } \\
\text { difference }\end{array}$} & $\begin{array}{l}\text { T statistics }(P- \\
\text { Value }\end{array}$ & Remark \\
\hline $\begin{array}{l}\text { Min-A-Min } \\
B\end{array}$ & -0.6900 & 6.5712 & 1.4694 & -3.76543 & 2.38543 & $-0.470(0.644)$ & $\begin{array}{l}\text { Not } \\
\text { Significant }\end{array}$ \\
\hline
\end{tabular}


World Journal of Innovative Research (WJIR) ISSN: 2454-8236, Volume-6, Issue-4, April 2019 Pages 21-24

\begin{tabular}{|l|l|l|l|l|l|l|l|}
\hline $\begin{array}{l}\text { Min A-Min } \\
\text { C }\end{array}$ & -5.55238 & 6.60164 & 1.44060 & -8.55741 & -2.54735 & $\begin{array}{l}-3.854 \\
(0.001 \text { ***) }\end{array}$ & $\begin{array}{l}\text { Not } \\
\text { Significant }\end{array}$ \\
\hline $\begin{array}{l}\text { Min B-Min } \\
\text { ( }\end{array}$ & -4.42000 & 3.31164 & 0.74050 & -5.96989 & -2.87011 & $\begin{array}{l}-5.969 \\
(0.000 * * *)\end{array}$ & $\begin{array}{l}\text { Not } \\
\text { Significant }\end{array}$ \\
\hline $\begin{array}{l}\text { Max A- } \\
\text { Max B }\end{array}$ & 1.295000 & 13.65112 & 3.05248 & -5.09392 & 7.68392 & $0.424(0.676)$ & $\begin{array}{l}\text { Not } \\
\text { Significant }\end{array}$ \\
\hline $\begin{array}{l}\text { Max A-Max } \\
\text { C }\end{array}$ & -3.64762 & 11.04670 & 2.41059 & -8.67602 & 1.38078 & $-1.513(0.145)$ & $\begin{array}{l}\text { Not } \\
\text { Significant }\end{array}$ \\
\hline $\begin{array}{l}\text { Max B-Max } \\
\text { C }\end{array}$ & -3.85000 & 7.26546 & 1.62461 & -7.25034 & -0.44966 & $\begin{array}{l}-2.370 \\
(0.029 * * *)\end{array}$ & $\begin{array}{l}\text { Not } \\
\text { Significant }\end{array}$ \\
\hline
\end{tabular}

Footnote: Sig. at $* * * 1 \%, * * 5 \%$ and $* 10 \%$

Next, the regression analysis was done between the Min A and Max A; Min B and Max B; Min C and Max C. The result is summarized in Table 3.0 as follow and a graph of the regress of Min A and Max A is shown in Figure 1.0 to 3.0 below.

Table 4: Regression analysis of Min and Max from A to D

\begin{tabular}{|c|c|c|c|c|}
\hline Models & $\begin{array}{l}\text { Coefficients } \pm \text { Std. Error (P- } \\
\text { Value) }\end{array}$ & $R^{2}(\%)$ & $\begin{array}{l}\text { ANOVA -F statistics } \\
\text { (P-value) }\end{array}$ & Remark \\
\hline Min A And Max a & $\begin{array}{l}\text { Constants: }-12.573 \pm 12.592 \\
(0.327) \\
\text { Coeff. (Min A): } 1.512 \pm 0.245 \\
\left(0.000^{* *}\right)\end{array}$ & 63.5 & $38.229(0.000 * * *)$ & High \\
\hline Min B and Max B & $\begin{array}{l}\text { Constants: } 14.419 \pm 19.011 \\
(0.458) \\
\text { Coeff. (min B): } 0.985 \pm 0.359 \\
\left(0.013^{* * *}\right.\end{array}$ & 29.4 & $7.513(0.013 * * *)$ & Low \\
\hline Min C and Max C & $\begin{array}{l}\text { Constants: } 49.963 \pm 10.017 \\
\left(0.000^{*}\right) \\
\text { Coeff. }(\text { Min C): } 0.355 \pm 0.175 \\
\left(0.056^{*}\right)\end{array}$ & 17.8 & $4.127\left(0.056^{*}\right)$ & Low \\
\hline
\end{tabular}

Footnote: $\operatorname{Sig} *=10 \% * *=5 \%$ and $* * *=1 \&$

The results in table 3.0 show a very high variability between the min A and Max A. Hence, the Min B Min C explained slight of their corresponding Max B, Max C (or explained 29.4\% 17.8\%), while min A explained 63.\%\% of its Max A.

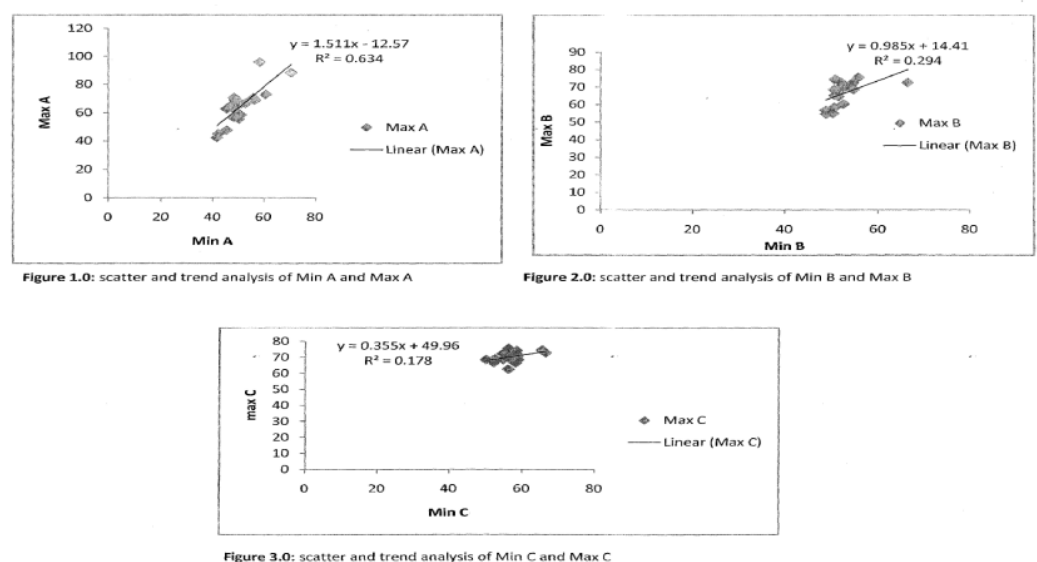

Figure 1 Scatter and trend analysis of Min C and Max C 


\section{SUMMARY AND CONCLUSION}

The study established that noise is the 3rd highest Hazard in our health sectors and institutions of learning. The first is waste management and hygiene, the second is mosquito and malaria infliction, the fourth is unemployment and social vices. The study recommend a well co-ordinated Health education scheme for the hospital management and staff as well as the students through their respective union and management.

The study recognized the importance of the utility department and their over stretch demand to meet hospital requirement and recommend the introduction of user pay principles based on pay as you go, even on waste management issues.

\section{NOISE ATTENUATION RECOMMENDATION}

The study recommends the following noise reduction measures

(1) Construction of sound shielding, screens or sound barrier by shielding the receiver from the direct source and impact of the sound (i.e. by portioning screen in wards).

(2) By the use of silencers and muffler to control noise from the engine exhaust by dissipative absorption method or by reactive reflection principles at the generator.

(3) By acoustic walls, ceilings or acoustical baffle and diffuseu's to absorb or reflect the sound from viscous flow, internal friction and panel vibration in open learning hall.

(4) By the use of an acoustic enclosure with network of diffusing piping, for attenuation of sound through and elongated part way e.g. sound proof generator.

(5) By the use of part way difference in barrier of very thick walling $\mathrm{T}$

$A=$ Sound travel part from source to barrier

$\mathrm{T}=$ Sound attenuated part in barrier thickness

$\mathrm{B}=$ Sound diffracted or emerged part to receiver

$\mathrm{D}=$ direct part way from sound source to receiver

\section{REFERENCES}

[1] Babisch, W. (2000). Traffic noise and cardiovascular disease: epidemiological review and synthesis. Noise \& Health, 2(8), pp. 9-32.

[2] Bahisch, W., Beule, B., Schust, M., Kersten, N., Ising. H. (2005). Traffic noise and risk of myocardial infarction. Epidemiology, 16, pp. 33-40.

[3] Belojevic, G.A., Jakovijevic, B.D., Stojanov, V.J., Slepcevic, V.Z., Paunovic, K.Z. (2008). Nighttime road-traffic noise and arterial hypertension in an urban population. Hypertension Research, 3 1(4), pp. $775-781$.

[4] Boden, T., Albin, M., Ardo, J., Stroh, E. Ostergren, P., Bjork, J. (2009). Road traffic noise and Hypertension: Result from a cross sectional public health survey in Southern Sweden. Environmental Health, 8, pp. 38.

[5] Chakraborty, D., Santra, S.C., Roy, B. (1998). Survey of community annoyance due to traffic noise-exposure in Calcutta metropolis. Journal of Acoustic Society of India, 26, pp. 3 9-43.
[6] Dutta, J.K., Sadhu, S.. Gupta, S., Saha, R..Mondol, N.K., Mukhopadhyay, B. (2006). Assessment of noise level in Burdwan town, West Bengal. Journal of Environmental Biology, 27(3), pp. 609-612.

[7] Gorai. A.K., Pal, A.K. (2006). Noise and its effect on human being-A review. Journal of Environmental Science and Engineering, 48, pp. 253-260.

[8] Guasch, 0., Magrans, F.X., Rodriguez, P.V. (2002). An inversion modelling method to obtain the acoustic power of the noise sources in a large factory. Applied Acoustics. 63, pp. 401-417.

[9] Gundogdu, O., Gokdag, M., Yuksel, F. (2005). A traffic noise prediction method based on vehicle composition using genetic algorithms. Applied Acoustics, 66, pp. 799-809.

[10] Lundberg, U. (1999). Coping with Stress: Neuroendocrine Reactions and Implications for Health. Noise \& Health, 1(4). Pp. 67-74.

[11] Neuman, C., Wroblewski. M., Hajicek. J. Rubinstein, A. (2010). Combined Effects of Noise and Reverberation on Speech Recognition Performance Normal-Hearing Children and Adults. Ear \& Hearing, 31, pp. 336-344.

[12] Pachpande, B.G., Patel, V.S., Patil, R.D., Girase, M.R., Ingle, S.T. (2005). Assessment of hearing loss in school 32 teachers and students exposed to highway traffic noise pollution. Journal of Eco physiology and Occupational Health, 5(1\&2), pp. 123-126.

[13] Peter, G.K., Rudy, J.M., Adam, K.S., Susan, B.B. (2008). Application of Prevention through Design for Hearing Loss in the Mining Industry. Journal of Safe Research, 39, pp. 251-254.

[14] Piccolo. A., Plutino, D., Cannistraro, G. (2005). Evaluation and analysis of the environmental noise of Messina, Italy. Applied Acoustics, 66, pp. 447-465.

[15] Prasher, D. (2003). Estimation of hearing damage from noise exposure, World Health Organization and European Centre for Environment and Health Report on the Technical meeting of exposure-response relationships of noise on health, Bonn, Germany, pp. 17-19.

[16] Rao, P.S., Gavane, A.G., Ankam, S.S., Ansari, M.F., Pandit, V.1., Nema, P. (2004). Performance evaluation of a green belt in a petroleum refinery: a case study. Ecological Engineering, 23, pp. $77-84$.

[17] Ogoke, U.P, Nduka, E.C, Biu, O.E, Ibeachu, C. (2013). A comparative study of foot measurements using receiver operating characteristics (ROC). International Journal of Pure \& Applied science ( scientia Africana)12 (i), pp.76-88.

[18] World Health Organization (WHO) (2005). Occupational and community noise. WHO Publications, WHO-OHS (2005). 